\title{
The Development of Carica Batik Motifs in Hyperreality Society
}

\author{
Savitri Wukirasih Milandari ${ }^{1, *}$ Martono ${ }^{1}$ Tomy Taufik Rafiqul Hadi ${ }^{1}$ \\ ${ }^{1}$ Graduate School of Art Education, Yogyakarta State University, Yogyakarta, Indonesia \\ *Corresponding author. Email: swmilandari@gmail.com
}

\begin{abstract}
This research discusses the rise of carica batik motif in contemporary culture. The recognition of batik internationally by UNESCO encourages artists to create unique batik motifs representing their region characters, as in the Wonosobo Regency, which produced the carica batik motif in the mid-2000s. It did not only form a new motif but also develop a brand-new batik. One of the progress signs is the combination of the batik motifs with existing traditional batik motifs, such as parang, sekarjagad, sidomukti, and other traditional motifs. The authors employed a cultural studies approach with the hyperreality theory by Jean Baudrillard. The theory discusses contemporary culture and hyperreality society related to the position of the noble values of material culture. As a result, the creation of batik in contemporary culture and an increasing hyperreality society only produce motifs based on the market needs, or only prioritizes popularity and ignores the existing noble values.
\end{abstract}

Keywords: Batik, Development, Cultural Studies, Hyperreality

\section{INTRODUCTION}

UNESCO recognizes batik as a human and cultural heritage. They see the technique of making batik, the symbolic meaning of batik, and the culture in batik which blends with the lives of Indonesian people. Batik is an Indonesian cultural heritage that has the main function as a clothing material. Batik is made specifically by using wax as a barrier in the batik dyeing process. In each region, batik provides its own characteristics. Various batik patterns in each region also represent their meanings. The tradition of making batik has been carried out from generation to generation in many various regions from childhood to adulthood. Batik production provides an economic prospect in a creative industry that can employ a lot of workforces because the manufacturing process needs hand skills or is labour-intensive. Currently, the development of batik industry is being intensified in various regions, especially with the international recognition of batik, which encourages each region to renew the motifs. Batik is now also increasingly diverse in motifs, one of which is in the Wonosobo Regency, Central Java. This regency produces relatively new motifs and patterns.

Batik craftsmen in the Wonosobo Regency are very enthusiastic in exploring batik by conducting experiments using a variety of materials, tools, and motifs. The result of creativity by the motif designer in designing and producing new motifs is an expression of regional culture and natural potential in the surrounding environment. Batik is known for its philosophical values representing the culture of Indonesian society. With this hyperreality society, batik motifs are not as typical as they were when we consider their philosophical values. Now, batik is widely developed to meet the consumer society that is more concerned with the market.

\section{LITERATURE STUDY}

Indonesia is a nation that has various ethnic groups in it; therefore, it is abundant with various customs, cultures, and traditions. One of Indonesia's cultural heritages is Batik. Batik was recognized by UNESCO on October 2, 2009, as a world heritage from Indonesia and designated as a human heritage for oral and non-material culture [2]. The motifs in the traditional Wonosobo batik are based on the typical plant shapes found in Wonosobo, and the development of the parang, kawung, and truntum motifs which are then combined with the shapes [1]. 
The motifs created are intended to preserve the batik culture and typical plant in the Wonosobo Regency [6]. The existence of Wonosobo batik began to appear around 2007 to 2008; this was marked by many batik craftsmen in the town [1]. Batik craftsmen in Wonosobo make various motifs and are generally inspired by the typical Wonosobo plant. One of the new motifs created is batik with the carica motif. The creation is an effort to make the carica motif a brand, even though it does not have a historical foundation [1].

\section{RESEARCH METHOD}

This was a qualitative study with a cultural studies approach. The new batik motifs that have risen in the Wonosobo Regency are regarded as conte mporary culture. It is claimed as an example of contemporary culture because the Wonosobo batik motif does not have a sacred philosophical value like the previous one. The batik craftsmen hope that this new batik motif can become a brand for Wonosobo [1]. This is an attempt by a region to gain recognition from outside or to form an identity by using batik as the medium. Identity by various thinkers is not seen as something finished, closed, and fixed, or as something that stands firmly, but something open, becoming, and transformable [7]. The existence meaning of people now is not determined by others but the objects around them. Regarding contemporary culture, it is inseparable from the term 'cultural studies', which is in line with the Piliang \& Jejen's statement [7]. Cultural studies is always multidisciplinary and interconnected with subjects within the discipline itself or with other disciplines. These parts sometimes present new and distinctive features in cultural studies. Culture is always considered a "species" that must reproduce to survive. The condition of the contemporary culture always presents a novelty - a novelty that is captured by eyes and the latest study approaches. Cultural studies, with multidisciplinary nature, almost always provides relevance to the latest socio-cultural developments in society [7].

Today, batik culture will continue to develop in terms of motifs, colors, characteristics, and the like based on the times and community conditions. Therefore, to study a culture that continues to progress, it is necessary to have a developing approach as well. Culture will continue to develop based on the conditions of the era and various aspects that can support life. Thus, the study of culture always requires a relatively dynamic method, and a cultural studies approach would be very appropriate to study contemporary culture in the Wonosobo Regency. Cultural studies experiences several developments, one of which happens during postmodernism. In this period, cultural studies is strongly influenced by postmodernism as a new trend of thinking. In the postmodern cultural studies phase, the issues raised shift towards various problems that become subject matter; the postmodernism movement involves issues of genesis, change, sign productivity, sign-free play, interpretation-free play, the relativity of knowledge, desiring machine, unconsciousness, and so on. At this time, cultural studies is influenced by "poststructuralist" thinkers such as Derrida, Barthes, Kristeva, and "postmodernists" including Foucault, Deleuze, Guattari, Lyotard, and Baudrillard [7]. Therefore, by using a cultural studies approach, the authors can use several theories from one of these experts to support the research results.

As mentioned above, the research employed a cultural studies approach. There is a study of important issues in cultural studies, namely reality and hyperreality. Therefore, in writing this article, the researchers referred to Jean Baudrillard's theory of hyperreality in studying the new batik motifs in the Wonosobo Regency. There are three levels of reality and representation, including presentation, representation, and simulation. Presentation is when the reality is faced without any form of technological mediation. In a presentation, something is present at the same time and place in reality. Furthermore, representation occurs when reality cannot be presented in front of us. Then, in representation, it is necessary to have mediation to bring back the reality using technological media, and reality is presented with certain media. The last one is a simulation. Simulation is when a fact is presented through a model without a reference to reality. In the simulation, the realization is presented without any reference from the real world. This condition is called hyperreality. That hyperreality is a condition that transcends all understandings of reality. Hyperreality is a creation - the creation of a real model or appearance without any real origin and reality.

Creating new motifs in today's era is a phenomenon of hyperreality societies in terms of culture. Consumer goods that are profane and daily needs are then associated with luxury, exotica, beauty, and romance with their original and functional "uses" that are increasingly difficult to describe. The aesthetic of reality underlies the significance of style, which is also driven by the dynamics of the modernist market with a constant search for new models, styles, sensations, and new experiences. The artistic idea of previous contemporary culture is manifested in the realm of modernism where life has to be a work of art to adapt to its wide circulation [4] 


\section{DISCUSSION}

Batik is a high-art craft and has become part of Indonesian culture. It is an ornament or decoration on fabrics with the process of covering it with wax which is then dyed or colored10]. The word batik comes from the Javanese language "amba" and "nitik" which mean writing [5]. The word batik itself also refers to a technique for making patterns or motifs through stamping (canting) and dyeing. The dyeing also uses wax which is applied to the fabric to withstand the dye. There are various types of batik including traditional batik, inland batik, and modern batik. Traditional batik has a motif style bound with certain rules and fillings (isen-isen) and does not experience changes or usually develops in a palace [8]. Inland batik develops in the inland areas of the Java island which still holds convention values from tradition and is not influenced by external elements. The strict rules of batik makers are often associated with mythology, expectations of gender viewers, social status, and even supernatural powers [11]. Moreover, modern batik has styles and motifs that are not tied to certain rules [8].

Wonosobo batik began to exist and was marked by the presence of batik craftsmen around 2007 2008 [1]. The craftsmen make batik with various motifs, some of which include carica, purwaceng, coffee, and other combination motifs. The new batik motifs found in Wonosobo are inspired by the natural potential of Wonosobo. The most popular motif is carica. The carica motif can become a characteristic of Wonosobo batik, which includes carica leaves, stems, and other combination motifs. Carica motif is more widely used, because it symbolizes a plant that is rare and only available in the Wonosobo Regency. This is the reason why the motif is claimed to represent the Wonosobo characteristic. Wonosobo's batik is dominated by carica motifs. Carica is a type of papaya tree that grows in mountains and can only be found in three places, namely Wonosobo (Dieng mountains, Indonesia), Russia, and Argentina [6]. Therefore, carica is the mainstay of the batik motif in the Wonosobo Regency.

The elements of batik motifs are a combination consisting of the main and supporting motifs that can strengthen the balance of the composition in the batik structure and fillings (isen-isen), which adds a beauty value. The product is in the form of printed and handdrawn batik. The carica motif has a naturalist shape of a carica leaf, which resembles a papaya leaf with sixleaf bones and curved stems. The basic size of the motif is $8 \mathrm{~cm}$ long, $7 \mathrm{~cm}$ for the leaf height, and $4 \mathrm{~cm}$ for the stem length [6].

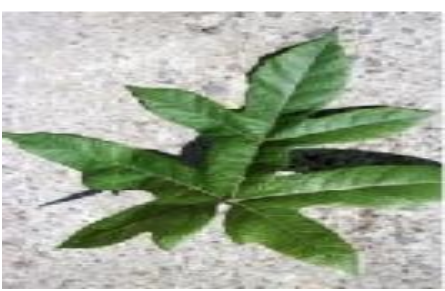

Figure 1. Carica Leaves

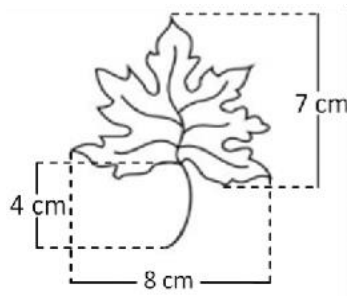

Figure 2. The Motif of Carica Leaf

A carica leaf is deconstructed into a motif. In addition, there is a carica motif which is similar to the carica fruit. The basic size of the fruit motif has a length of $4 \mathrm{~cm}$ and a height of $3 \mathrm{~cm}$, and the size of the additional stem is $1 \mathrm{~cm} \mathrm{[6].}$

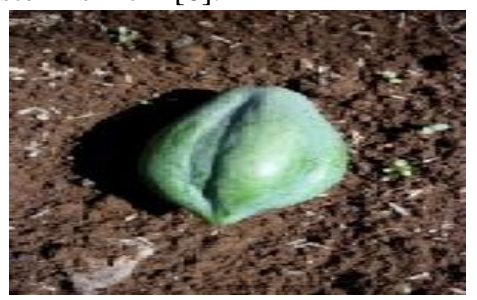

Figure 3. Carica Fruit

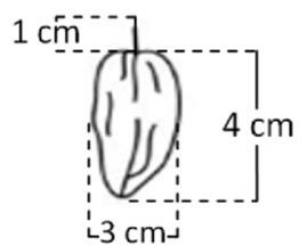

Figure 4. The Motif of Carica Fruit

After the carica leaf and fruit motifs are created, a stamp is then made with a specified motif. One of the examples shown is printed batik.

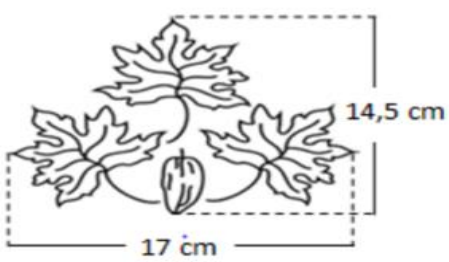

Figure 5. Carica

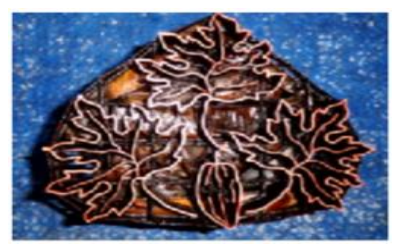

Figure 6. The Carica Motif 
The color of carica batik is dominated by bright colors; this is meant to give a warm impression to the wearer [6]. The character in carica batik is the use of hot colors.
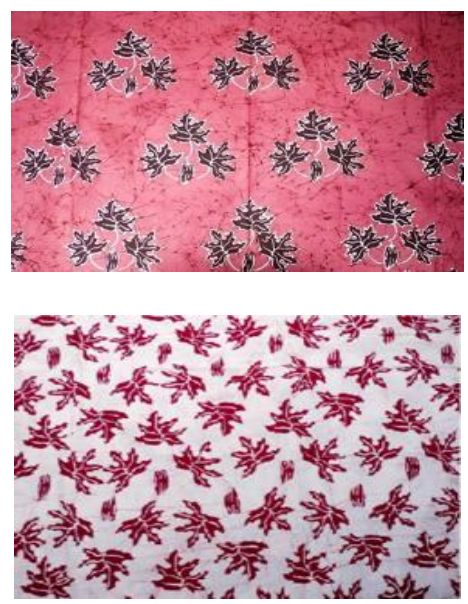

Figure 7. Two Examples of Carica Batik

It is a predominantly red carica batik motif. Batik with motifs are most in-demand and it is hoped that the carica motifs can become the brand for the Wonosobo Regency. Today, many cities are competing to make batik designs for an identity or brand of an area, one of which is Wonosobo. The carica motif is created because of the regional expectation to have a cultural identity. Cultural identity is a social construction and can be expressed through various forms of representation that can be recognized by other people [9]. Therefore, an identity can be interpreted through signs such as tastes, beliefs, attitudes, lifestyle, and even political involvement. As in the carica batik, the motif is inspired by the natural potential of the Wonosobo Regency, namely carica agriculture, and it is also stated that in Indonesia, carica only grows in Wonosobo. This is the main reason why carica batik can be claimed as the identity of the Wonosobo Regency. The motif is not only presented with the original carica, but in this era of hyperreality, carica batik is combined with previous batiks that possess a philosophical and strict rule about the motif and the wearer, such as batik parang, sekar jagad, sidomukti, and others.

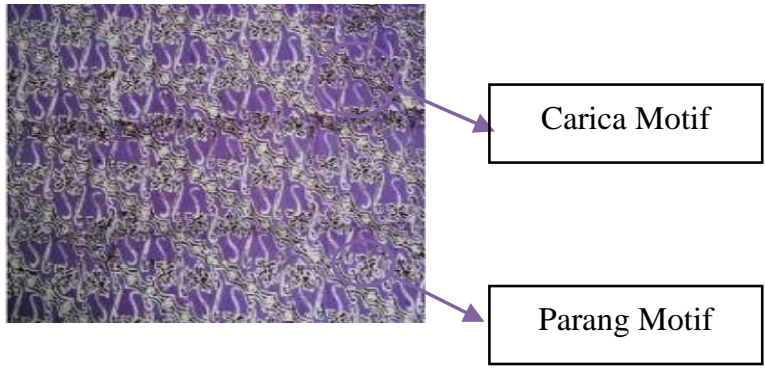

Figure 8. The Combination of Carica and Parang Motifs

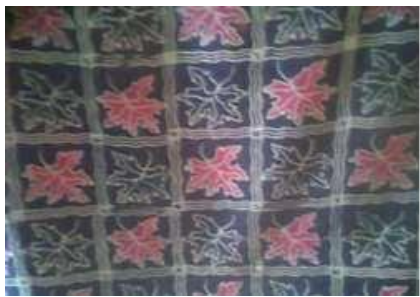

Figure 9. The Combination of Carica and Sidomukti Motifs

In Figure 5, a parang motif is combined with the carica leaf motif. However, the people of Wonosobo generally call it the rejeng motif [6]. The parang motif has a sacred and deep philosophical meaning. Meanwhile, Figure 6 shows sidomukti batik which is combined with carica motif. Sidomukti batik is one of the classic batiks and it is commonly used in wedding ceremonies, which has existed since ancient times [1]. Also, it has geometric motifs that form squares, each of which is filled with motifs of butterflies, living trees, buildings, and garuda [1]. Conceptually, it resembles the original sidomukti, but the fills in the squares are replaced with carica motifs.
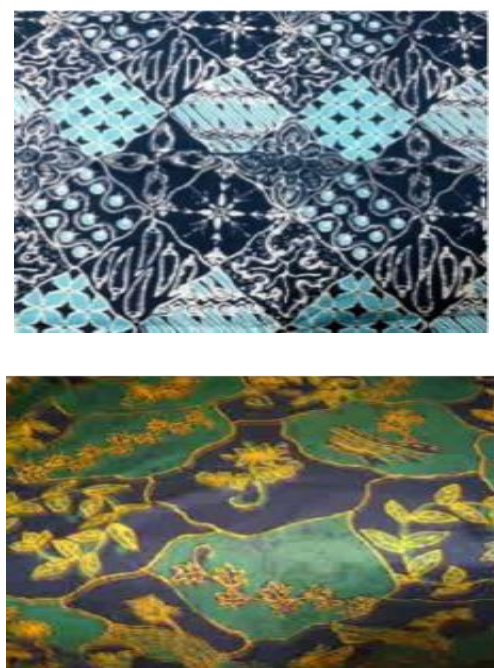

Figure 10. The Combination of Carica and Sekarjagad Motifs

Figure 7 is the Sekarjagad batik motif combined with the carica motif. Sekarjagad is batik with floral motifs and many flower motifs used as fillings in it. In this batik sekarjagad carica, the motifs of various kinds of flowers are filled with carica motifs. Referring to the examples of carica and combination motifs in today's hyperreality society, the presence of the carica batik motif can also be regarded as mass culture, the culture that grows in a particular society, based on the existing principles, forms, and values in it [7]. This is related to a modernist aesthetics, an attempt to rejuvenate art in a society, which has lost its meaning [13]. 
Freedom in creating a culture is manifested through objects such as batik by developing and combining the traditional batik and then ignoring its philosophical values. This happened for the sole purpose of commodities. The development of commodity production that goes hand in hand with the development of information technology leads to 'cultural victory that provides significance' which then reverses the direction of determinism; therefore, social relations are full of changing cultural signs and people cannot talk about class or normativity and deal with 'societal ideals'. Baudrillard also says that the most important characteristic of the movement towards the mass production of various commodities is that the loss of the values - true benefit of things due to the domination of exchange rates in capitalism that has made commodities a sign, in the Saussurean definition, which is inconsistently determined by its position in the self-referential marker system [5]. The sign system is not only imitating, duplicating, or even parodying the original object, but also substituting the actual sign [3]. A reality is always a construction. Today's culture is the result of constructed reality or "hyperreality", the domination of sign systems, "symbolic values" that replace the exchange and use values as a driving force for the economy and society.

This means that creating new motifs which are then combined with the existing traditional batik only promotes popularity. It is a popularity that only emphasizes a trend to make it look more attractive. Combining the traditional motifs is expected to help introduce the new carica motif and use the power of mass media to support the development. This is because mass media function to neutralize the real and unique characteristics and to replace the diverse world with a homogeneous world one another, which interprets one another and sends back to one another [11]. Hyperreality is a term used to describe ways the world is absorbed by individual preferences for illusory objects rather than real objects. This is carried out by modifying cultural objects or icons to make them more attractive than their original forms [13]. Popular culture cannot be separated from industrialization, capitalism, and consumerism [7]. The carica motif which is intended to be a brand and an identity for the Wonosobo Regency is deemed less emphasizing the values. Art is not reality; it is not meant to convey the truth. Imitating the previous batik and inserting the carica motif into it is not enough to bring up the values to highlight the carica motif [13]. This is related to popular culture; the popular culture encourages the mass to become followers, imitators, copyists, or initiators. Later, people will be confused with the original one of the two motifs. there is no longer a fake from the original, and people deal with a reality of inability to recognize the original one [7].

\section{CONCLUSIONS}

Today's contemporary culture and hyperreality cause culture to also develop. One form of material culture that is increasingly developing is batik motif. Batik motifs are now not only experiencing development but also becoming a brand or an identity. In the past, traditional batik was produced based on its sacred philosophy, but now the increasing hyperreality of people's desire to make a batik motif can be inspired from anywhere, such as regional natural products, wealth, icons, and trending things, as found in the carica batik motifs. Carica batik motif is inspired by the natural products (Carica plants) in the Wonosobo Regency. In addition, now the new motif is also combined, and some are imitating the traditional batik motifs. This shows that cultural development does not see the philosophical value of each batik. It is very unfortunate to create a cultural object without strong values in a society. Today's batik motifs are more concerned with market demand and physical beauty, so noble values are put aside. In fact, by developing and highlighting the features of the carica motif itself, it will be more recognizable and distinctive. Later, the new motif which is expected to become a regional identity will not be able to compete with the combination of carica and previous traditional batik motifs. Therefore, to realize a hope that the carica batik motif is an identity of the Wonosobo Regency, it would be better if the progress made is only on the motif itself, including shapes or colors. This is to inform the public that the carica motif itself can describe the natural wealth of Wonosobo, which does not exist in other areas. The motif should not be combined with the previous traditional batik to prioritize a market demand only. In addition, introducing the natural wealth and culture in the area to students is an effort to preserve new culture. They will find out the richness of the natural resources and batik culture.

\section{REFERENCES}

[1] Alamsyah, Alamsyah. Perkembangan Motif Batik di Wonosobo [The Growth of Batik Motifs in Wonosobo]. Endogami: Jurnal Ilmiah Kajian Antropologi 2.2: 158-175. DOI: https://doi.org/10.14710/endogami.2.2.158-175

[2] Siregar, Aminuddin. Apresiasi dan Ekspresi Seni Rupa [Appreciation and Expression of Arts]. (2009).

[3] Cempaka, Putri Surya, and Johannes Haryatmoko. Hyperreality among defense of the ancients 2's players. Jurnal Komunikasi Indonesia (2019): 225-234. DOI: https://doi.org/10.7454/jki.v7i3.9678

[4] Featherstone, Mike. Posmodernisme dan budaya konsumen. Pustaka Pelajar, [Modernism and 
Consumer Culture]. Yogyakarta: Pustaka Pelajar. 2001.

[5] Hamidin, Aep S., and Lilih Prilian Ari Pranowo. Batik Warisan Budaya Asli Indonesia [Original Indonesian Cultural Heritage Batik]. Narasi, 2010.

[6] Hidayati, A. Batik Carica di Home Industry Batik Carica Lestari Desa Talunombo Sapuran Kabupaten Wonosobo Jawa Tengah [Carica Lestari Batik, Talunombo Sapuran Village, Wonosobo Regency, Central Java]. Skripsi. Fakultas Bahasa dan Seni. Pendidikan Seni Rupa. Universitas Negeri Yogyakarta. 2013. Unpublished.

[7] Piliang, Yasraf Amir, and Jejen Jaelani. Teori budaya kontemporer: penjelajahan tanda dan makna [Contemporary cultural theory: the exploration of signs and meanings]. Yogyakarta: Aurora (2018).

[8] Sa'du, Abdul Aziz. Buku Panduan mengenal dan membuat Batik [Guide book to know and make Batik]. Jogjakarta: Harmoni (2010).

[9] Sari, R. K. N. Prosiding Seminar Pascasarjana Kajian seni Nusantara: Tradisi dan Kontenporer [Proceedings of the Postgraduate Seminar on Archipelago Arts Studies: Traditions and Exporters.]. Surakarta: ISI Press. 2017

[10] Setiawati, Puspita. Kupas tuntas teknik proses membatik: dilengkapi teknik menyablon. Absolut, 2005.

[11] Baudrillard: Work and Hyperreality. Redalyc Sistema de Information Cientifica

[12] Thiry-Cherques, Hermano Roberto. Baudrillard: work and hyperreality. RAE-eletrônica 9.1 (2010).

[13] Torikian, G. J. Against a Perpetuating Art from Hyperreality. The Journal of Aesthetic Education, 44, 100-110Thiry-Cherques, H. R. (2010).

[12] Weiss, Martin. Reality, Simulation and Hyperreality: An Essay on Baudrillard. International Journal of Baudrillard Studies 8.2 (2011).)

[15] Wulandari, Ari. Batik Nusantara: Makna Filosofis [Batik Nusantara: Philosophical Meanings]. Cara Pembuatan (2011). 